\title{
Migration of the Western Marsh Harrier to the African wintering quarters along the Central Mediterranean flyway: a 5-year study
}

\author{
Nicolantonio Agostini ${ }^{1 *}$ (D), Michele Panuccio ${ }^{1,2}$, Alberto Pastorino ${ }^{1}$, Nir Sapir ${ }^{3}$ and Giacomo Dell'Omo ${ }^{2}$
}

\begin{abstract}
Background: The Western Marsh Harrier (Circus aeruginosus) is a partial migrant with the populations from Eastern and Northern Europe migrating south to sub-Saharan Africa. During the autumn migration, that is peaking in September, harriers move on a broad front heading SW and undertake long sea-crossings en route to their wintering quarters, passing in substantial numbers through Italy and Malta with the highest concentrations recorded at the Strait of Messina. Most of the individuals migrating across the Strait are heading for the wintering quarters in Africa, while fewer spend the winter in Sicily.

Methods: In a 5-year study (2011-2015), between 26 August and 30 September, we determined age and sex of autumn migrating harriers through this flyway. In 2014 we determined, by marine radar and optical range finder, the flight altitude of migrating harriers.

Results: A total of 10,261 Western Marsh Harriers were counted during the whole study, with an average of 2052 per autumn season. Adults outnumbered juveniles and males outnumbered females. Harriers flew at lower altitudes during the morning while large flocks flew lower than single birds or small flocks.

Conclusions: Our observations are consistent with previous surveys and confirm that adult males have a tendency to migrate over a long distance, while substantial numbers of adult females and juveniles do not head for the wintering quarters in Africa. Finally, flight patterns recorded can be explained by a more pronounced flapping flight of Western Marsh Harriers during migration.
\end{abstract}

Keywords: Western Marsh Harrier, Migration, Mediterranean, Flight altitude, Radar

\section{Background}

The Western Marsh Harrier (Circus aeruginosus) is a raptor showing a leap-frog migration pattern, with populations from Eastern and Northern Europe migrating south to Sub-Saharan Africa (Ferguson-Lees and Christie 2001; Panuccio et al. 2013a). Unlike broad and rounded winged species, which mostly migrate over land using soaring flight exploiting thermals and updrafts, harriers move on a broad front, undertaking long sea-crossings (for a review see Agostini and Panuccio 2010). Since thermals are very weak over water, at least in temperate zones, sea

\footnotetext{
*Correspondence: nicolantonioagostini@gmail.com

${ }^{1}$ Medraptors, Via Mario Fioretti 18, 00152 Rome, Italy

Full list of author information is available at the end of the article
}

crossing implies a long powered flight with considerable expenditure of energy (Kerlinger 1989). Yet, harriers have morphology and size allowing them to use this flight style for a long duration (Spaar and Bruderer 1997; Panuccio et al. 2013b; Agostini et al. 2015). During both spring and autumn, large numbers of Western Marsh Harriers move through the Central Mediterranean flyway where substantial concentrations have been reported at several watchsites, peaking in late March/early April and in September, respectively (Agostini and Panuccio 2010). Previous field surveys made at different watchsites and during specific autumn migrations in 1996 and 2002 have suggested that, among adult Western Marsh Harriers, larger numbers of males head to the wintering quarters in Africa (Agostini and Logozzo 1997, 2000; Agostini et al. 
2003; Panuccio et al. 2005). The aim of this study was to verify these results by analyzing data collected over 5 years. We used visual observations to count the birds and determine age and sex, and during 2014 we additionally deployed a marine radar and an optical range finder to measure the birds' flight altitude.

\section{Methods}

\section{Study area}

Along the central Mediterranean flyway, involving Italy, Tunisia, Malta and western Libya, the highest concentration of Western Marsh Harriers was found at the Strait of Messina (Agostini and Panuccio 2010), the narrowest water surface (minimum distance about $3.5 \mathrm{~km}$ ) between southern continental Italy and eastern Sicily. Observations were carried out in southern continental Italy at a watchsite $\left(38^{\circ} 12^{\prime} 54^{\prime \prime} \mathrm{N}, 15^{\circ} 49^{\prime} 25^{\prime \prime} \mathrm{E}\right)$ on the Calabrian Apennines on a flat highland (Aspromonte plateau, altitude $1000 \mathrm{~m}$ a.s.l.) west of the major mountain ridge in this area (Fig. 1).

\section{Visual observations}

Observations, aided with binoculars and telescopes, were carried out from 26 August to 30 September 2011-2015, each day from 9.00 a.m. until dusk. We divided the 36 days of observation into seven periods (one six-day in August and six five-day in September) and focused on the migration of adult males, adult females, and juveniles (first calendar year birds) based on the birds' plumage attributes (Forsman 1999, 2016), when possible. Other individuals were not identified to a specific age and sex class. The totals of adult males, adult females and juveniles were derived following the method used by Kjellén (1992). In particular, to limit a possible bias resulting from an easier identification of adult males, a proportion of Western Marsh Harriers (18\%; total $n=10,261)$ was labelled "fem/juv" meaning that they were either adult females or juveniles. Then, the group "fem/juv" was divided between females and juveniles according to their proportions among identified individuals for each period. The total proportions of different sex and age classes were estimated on the basis of the sample of identified

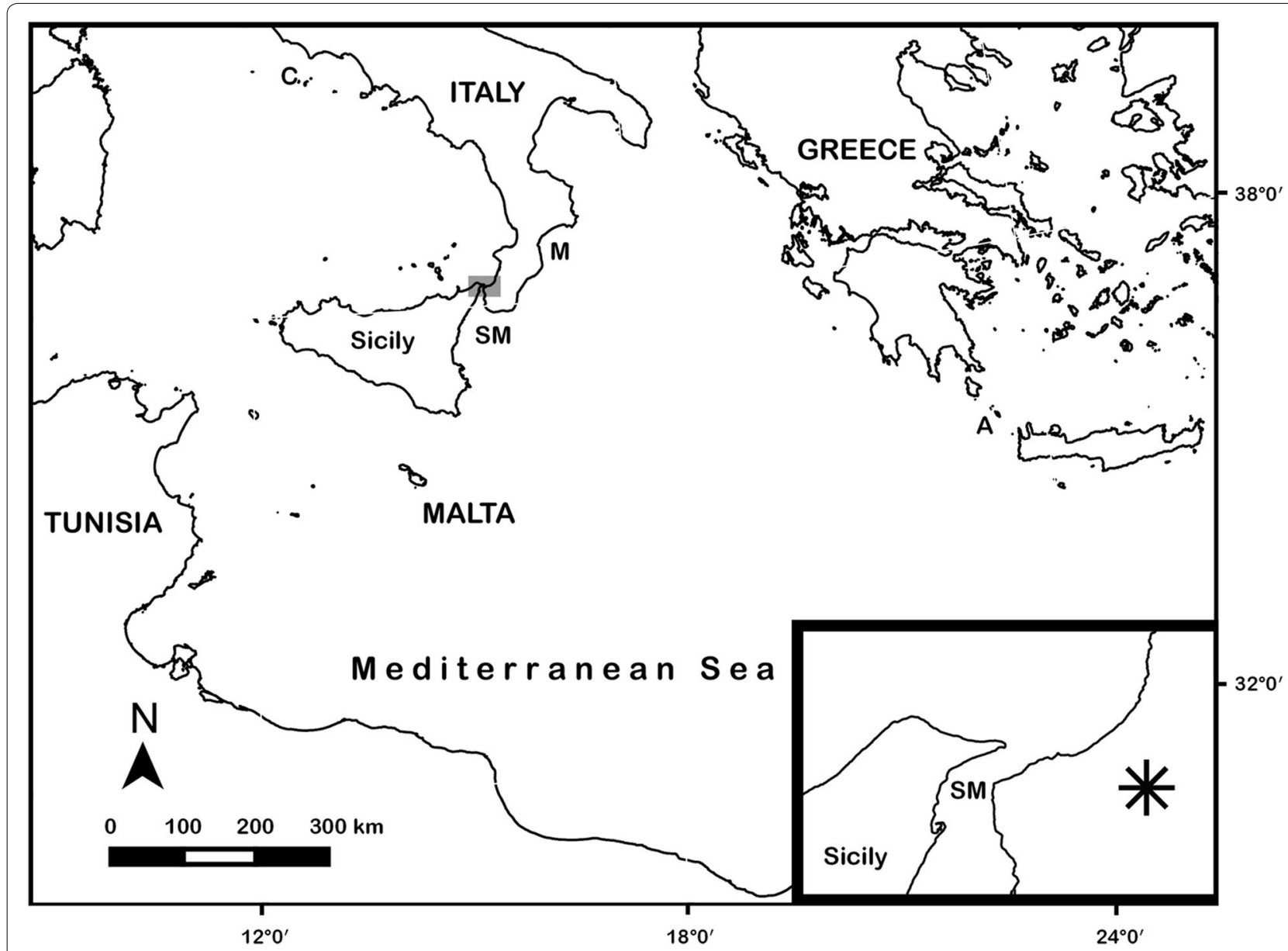

Fig. 1 The study area (C Circeo Promontory, M Marcellinara Isthmus, SM Strait of Messina, A Antikythira island). The asterisk shows the watchsite 
individuals after this "correction", weighted by the total number of individuals in each of the seven periods. For example, if $20 \%$ of the identified Western Marsh Harriers (after "bias correction") in the last five-day period of September during the 5 years were juveniles, $20 \%$ of the unidentified (individuals not identified to a specific age and sex class and not labelled as fem/juv) Western Marsh Harriers in this period were also assumed to be juveniles (see also Agostini and Logozzo 2000; Agostini et al. 2003).

\section{Radar and optical range finder data}

In autumn 2014 we used a 12-kW, X-band $(9.1 \mathrm{GHz})$ marine surveillance radar with a 7.1-foot antenna set vertically and rotating at $38 \mathrm{rpm}$. The radar and the ornithologists carrying out the observations were in close proximity (i.e., $50 \mathrm{~m}$ ) from each other. When possible, radar echoes were assigned to a specific observed individual of a particular species or flock of birds for which flock size was determined, following a method described in a previous study (Panuccio et al. 2016). We recorded $1 \mathrm{~Hz}$ videos of the radar screen that were processed using the radR package in R software (Taylor et al. 2010), allowing the assignment of coordinates and time stamps to radar detected targets. Furthermore, echo data were imported into QGIS software (QGIS2015) for visual inspection. We measured the flight altitudes of raptors passing close the observers using a Leica optical range finder (Rangemaster 1600).

\section{Statistical analysis}

Data were analyzed using Mann-Whitney $U$ tests to examine if bird abundance and flight altitudes varied during the day among three time intervals corresponding to the morning (09:00-11:59), midday (12:00-14:59) and afternoon (15:00-sunset, solar time) hours using paired tests (morning vs. midday; morning vs. afternoon; midday vs. afternoon). A linear regression was used to examine the relationship between flock size (independent variable) and flight altitude (dependent variable). We evaluated the model fitness checking the normal distribution of the model residuals by applying a Shapiro-Wilk test.

\section{Results}

A total of 10,261 Western Marsh Harriers was counted during the 5-year period, on average $2052 \pm 271$ (SE) per autumn season (Table 1). It was possible to determine age and sex or at least to label as fem/juv a total of 5599 birds (54.6\% of the birds counted; adult males $=2087$; adult females $=706$; juveniles $=963$; fem $/$ juv $=1843)$ and this allowed to estimate the passage of $6502(63.4 \%)$ adults and 3759 (36.6\%) juveniles during the seven periods
Table 1 Number of Western Marsh Harriers counted at the watchpoint inland of the Strait of Messina between 26 August and 30 September 2011-2015

\begin{tabular}{ll}
\hline Year & Number of Western Marsh Harriers \\
\hline 2011 & 2070 \\
2012 & 1397 \\
2013 & 2541 \\
2014 & 1496 \\
2015 & 2757 \\
\hline
\end{tabular}

along the season, as explained above. Overall, the migratory flow was characterized by two peaks during the season, from 6 to 10 and from 21 to 25 September. Noteworthy, both juvenile and adult numbers were the highest in the second peak of harriers along the season (21-25 September; Fig. 2). Among adults, males (58\%) outnumbered females (42\%).

We collected 114 records of flight altitudes. The mean flight altitude was $321.7 \pm 14(\mathrm{SE})$ meters above the ground level. We found a negative relationship between flock size and flight altitude $(\beta=-13.0 \pm 4.0 ; t=-3.2$, $d f=1, p<0.01$; model residual: Shapiro-Wilk test: $W=0.99, p>0.05)$, indicating that the altitude of larger flocks was lower than that of single individuals and small flocks (Fig. 3). Moreover, flight altitude varied during the day (Fig. 4) being lower during the morning (mean $279.3 \pm 13$ (SE); median 226.1) than, both, during midday (mean $408.0 \pm 39.5$ (SE); median: 397.4; morning $v s$ midday: $U=675.5, p<0.001)$ and during the afternoon

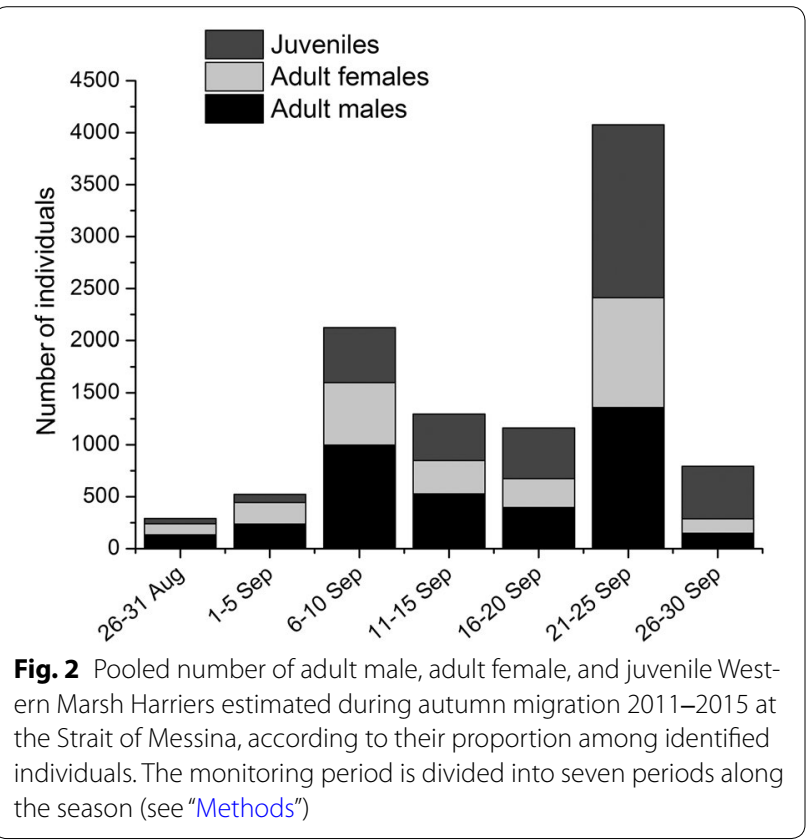




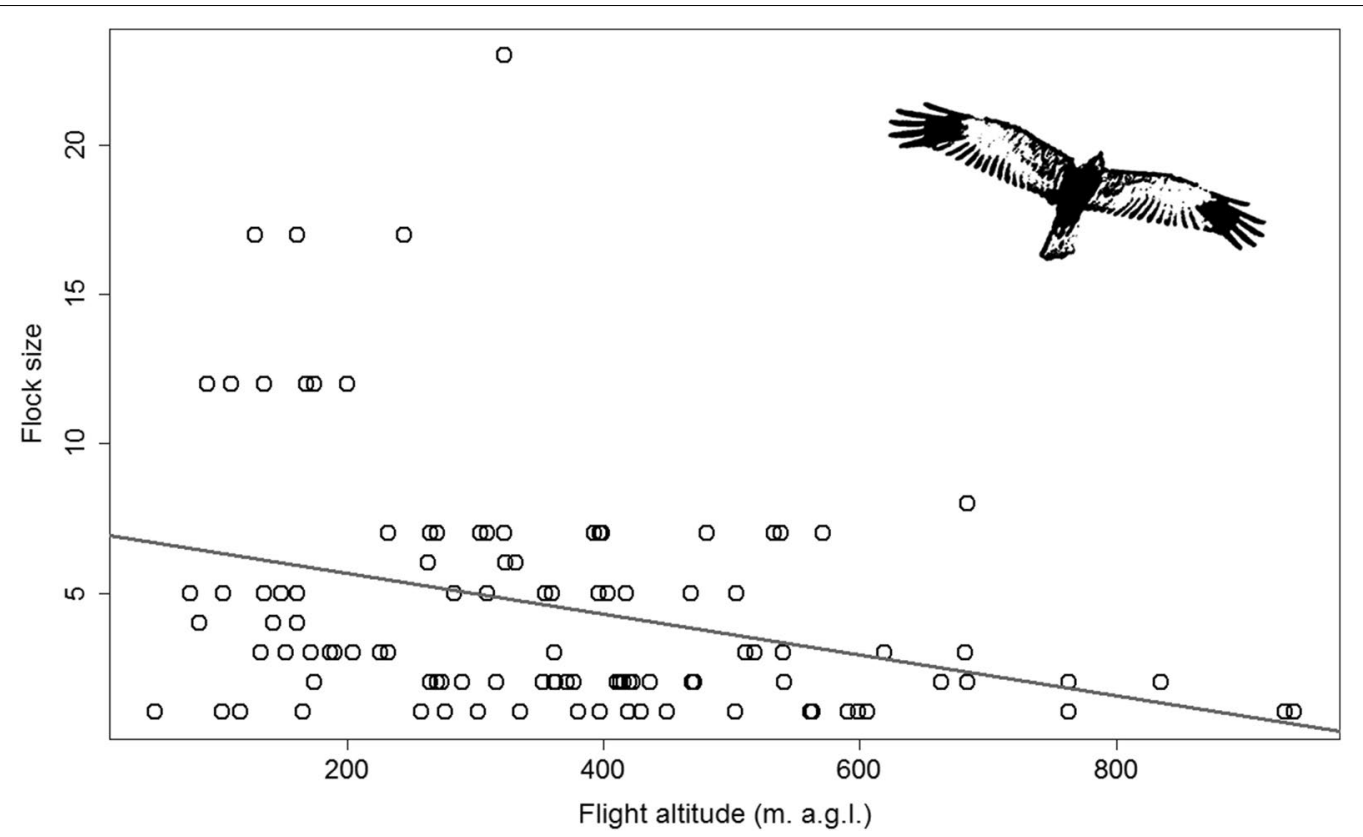

Fig. 3 The relationship between flock size and flight altitude of Western Marsh Harriers

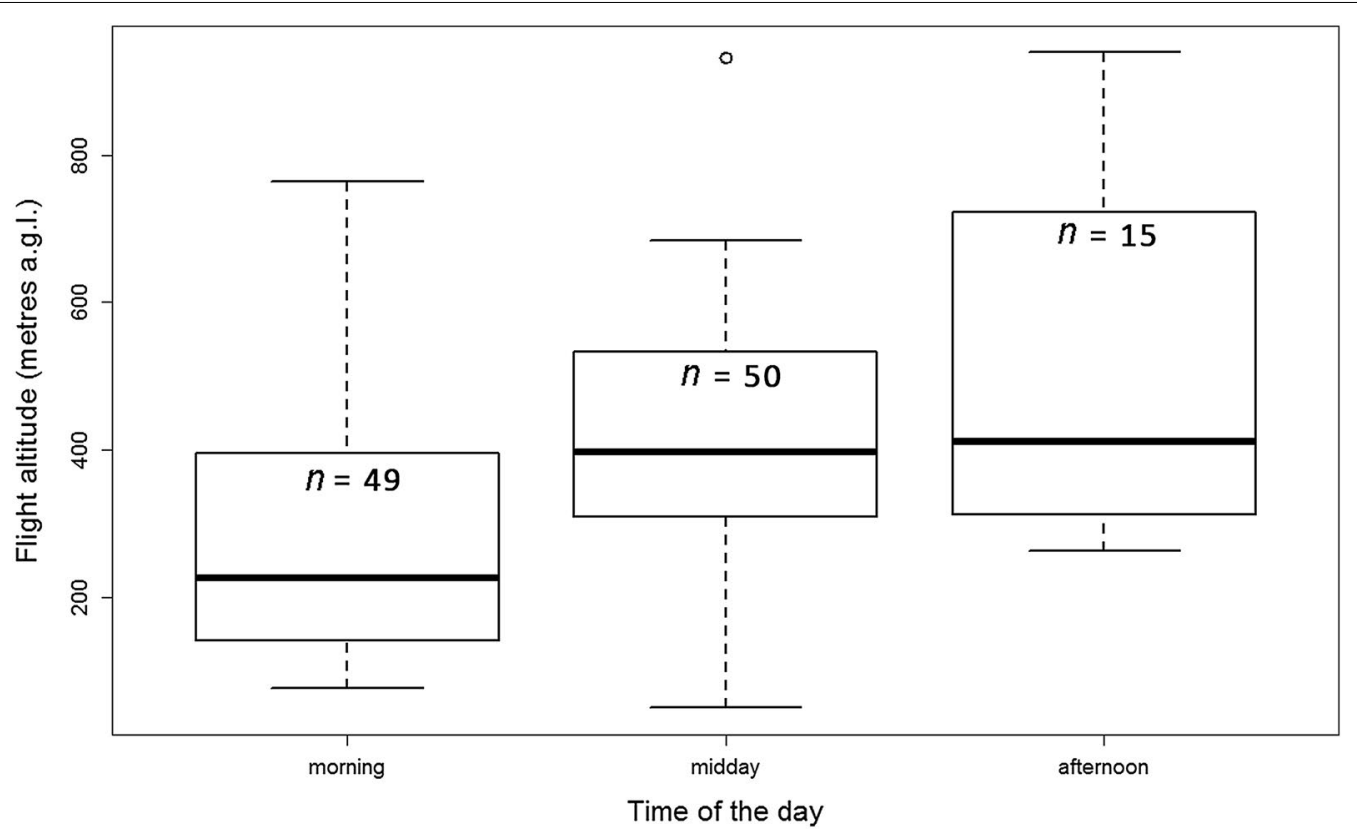

Fig. 4 Flight altitude of Western Marsh Harriers during the day, recorded in 2014 in the Aspromonte mountain (Strait of Messina). The horizontal bold lines show the median flight altitude of each slot. The bottom and top of boxes show the 25 and 75 percentiles, respectively. The horizontal line joined to the box by the dashed line shows the maximum and the minimum range of the data. Points are outliers

(mean $513.1 \pm 94(\mathrm{SE})$; median: 411.8; morning $v s$ afternoon: $U=125.5, p=0.002)$. The flight altitude of harriers was not statistically different between midday and afternoon $(U=247, p=0.3)$.

\section{Discussion}

Our results are consistent with previous surveys carried out during a single season in central (Circeo promontory; Agostini et al. 2003) and southern Italy (Marcellinara 
Isthmus; Agostini and Logozzo 2000), Malta (Agostini et al. 2003), and southern Greece (Antikythira; Panuccio et al. 2013b; Fig. 1) and confirm that adult birds are observed in larger numbers than juveniles, and that adult males are more frequent than adult females. This is in accordance with the hypothesis that adult males migrate over a longer distance to the wintering quarters in Africa, while many adult females (Agostini et al. 2003) and many juveniles may stay in relatively higher latitudes during the winter (Agostini and Logozzo 2000; Panuccio et al. 2005). In particular, age and sex composition of birds recorded in our study was similar to that recorded in previous surveys made in 1996 at the Marcellinara Isthmus (approx. $100 \mathrm{~km} \mathrm{NE}$ of the Strait of Messina) and in 2002 at the Circeo promontory (Agostini and Logozzo 2000; Agostini et al. 2003). Conversely, a higher proportion of adult males was reported over Malta in 2002 (Fig. 5), possibly because significant numbers of adult females winter in Sicily (Agostini and Logozzo 2000; Panuccio et al. 2005). Similarly, a higher proportion of adult females and juveniles was reported in northern Greece rather than in southern Greece during autumn migration (Panuccio et al. 2013b). The stronger tendency of male Western Marsh Harriers to migrate over longer distances has been related by some authors to their smaller body size and the need to avoid intraspecific sex competition (Agostini and Logozzo 2000; Panuccio et al. 2005). In fact, according with the "body size hypothesis" (Bergmann's rule), the smaller male harriers (Cramp and Simmons 1983), might be disadvantaged when competing

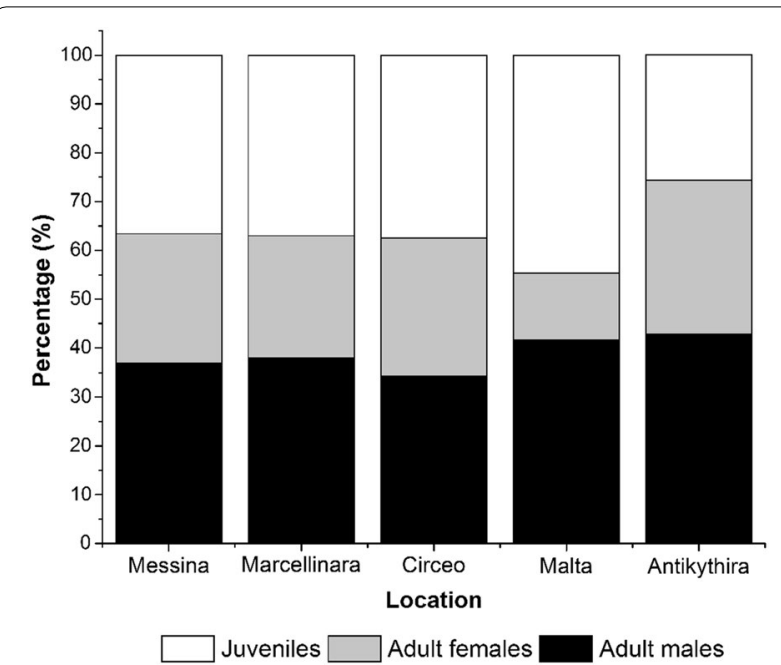

Fig. 5 Percentage of adult males, adult females and juveniles recorded at the Strait of Messina (this study), at the Marcellinara Isthmus (in 1996; Agostini and Logozzo 2000), at the Circeo promontory (in 2002; Agostini et al. 2003) and over the islands of Malta (in 2002; Agostini et al. 2003) and Antikhytira (in 2009; Panuccio et al. 2013b) with the larger females in the same areas during winter time, since females may tolerate colder weather, could fast for a longer duration and may capture larger preys (Bergmann 1847; Newton 1979; Clarke 1995; Blackburn et al. 1999; Simmons 2000; Olson et al. 2009). Therefore, males may move further south to avoid both competition and harsher environmental conditions. As suggested by Agostini et al. (2003), this conclusion may predict a male-biased population of Western Marsh Harriers that over-winter in Africa, which nevertheless may also include juvenile and immature male birds. Male harriers are smaller than females both among adults and juveniles (Cramp and Simmons 1983). Finally, our data confirm a large overlap in the migration periods of individuals belonging to the two age classes (see Agostini and Panuccio 2010).

Our counts indicated a higher number of birds migrating over the area compared with surveys made at the Marcellinara Isthmus between 1992 and 1996, where a maximum of 460 Western Marsh Harriers was counted (in 1996) from a single watchpoint (N. Agostini unpublished data; Agostini and Logozzo 1995, 1997). Our counts were also higher than those reported for Malta in 1990s (Coleiro et al. 1996), but almost the same as the most recent ones made over the island (Sammut et al. 2013). In particular, in 1994 and 1995 Coleiro et al. (1996) reported a total of 526 and 384 individuals, respectively, while between 2009 and 2012, $2052 \pm 428$ (SE) harriers were counted on average per autumn season (Sammut et al. 2013). These results confirm the trend of population increase recorded both in Eastern and Northern Europe since 1970 (del Hoyo et al. 1994; Clarke 1995; BirdLife International 2004).

Flight altitudes of harriers recorded in our study were lower than those recorded in a previous study with the radar positioned slightly above sea level on the continental coast of the Strait of Messina during spring migration (mean $450 \mathrm{~m}$ a.g.l., Mateos-Rodríguez and Liechti 2012). This difference could be explained since during the crossing of the water body, Western Marsh Harriers likely did not greatly decrease their altitude by using the flapping flight to a larger extent than other soaring raptors such as the European Honey Buzzard, which in the same study was detected reaching the coast flying at lower altitude (Mateos-Rodríguez and Liechti 2012). Our flight altitude data were also lower than those reported during the autumn migration over land in southern Israel (550 $\mathrm{m}$ a.g.l.) but were similar to the altitudes recorded in spring at the same location (315 m a.g.l., Spaar and Bruderer 1997). In this regard, it is interesting to note that the mean maximum temperature recorded in September at our radar station was $23.1 \pm 1{ }^{\circ} \mathrm{C}$ and was very similar to that reported for the Arava Valley (Israel) in March 
$\left(25^{\circ} \mathrm{C}\right)$, the spring peak period of the Western Marsh Harrier, but quite lower than that reported there in September, the autumn peak period $\left(35^{\circ} \mathrm{C}\right.$; Shirihai et al. 2000; Goldreich and Karni 2001). Therefore, flight altitude may be primarily dictated by ambient temperature that could strongly affect the development of thermals that are used by migrating Western Marsh Harriers during soaring flight. As a result, Western Marsh Harriers are detected flying over land at higher altitudes in watchsites and seasons with higher temperatures (e.g. during autumn migration in southern Israel; Spaar and Bruderer 1997).

Our results concerning the variation of the flight altitude during the day partially agree with those recorded in Israel where Western Marsh Harriers increased their flight altitude during the afternoon (Spaar and Bruderer 1997). Furthermore, we found a negative relationship between flock size and flight altitude. Apparently, unlike more obligatory soaring species (Kerlinger 1989), Western Marsh Harriers do not use flocking to locate thermals during migration. This is not surprising when considering that, as mentioned above, harriers are more prone to use flapping flight during migration (Spaar and Bruderer 1997; Mellone et al. 2012), showing irregular flocking and mostly flying singly or in small flocks (Kerlinger 1989; Agostini and Logozzo 2000; Panuccio 2011).

\section{Conclusions}

This 5-year study confirms that among adult, and probably among juvenile Western Marsh Harriers migrating along the central Mediterranean flyway, larger numbers of males head to the wintering quarters in Africa. Raptors increased their flight altitude during midday and afternoon, partially in accordance with the findings of a previous radar study. Moreover, birds migrating in larger flocks were detected at lower altitudes, suggesting that this species does not use flocking to locate thermals.

\section{Authors' contributions}

NA made bird observations, prepared data for analysis and wrote the first draft of the manuscript. MP led the study at the radar station, made bird observations and did all the statistical analyses. AP made bird observations and worked at the radar station. NS and GD helped with the writing of the text and the study design. GD provided all the instruments of the radar station. All authors read and approved the final manuscript.

\section{Author details}

${ }^{1}$ Medraptors, Via Mario Fioretti 18, 00152 Rome, Italy. ${ }^{2}$ Ornis italica, Piazza Crati 15, 00199 Rome, Italy. ${ }^{3}$ Animal Flight Laboratory, Department of Evolutionary and Environmental Biology, University of Haifa, 199 Aba Khoushy Ave. Mount Carmel, 3498838 Haifa, Israel.

\section{Acknowledgements}

This research has been supported by TERNA Rete Italia S.p.A. and by Parco Nazionale dell'Aspromonte. Additional support for the fieldwork was given by Ornis italica and by Mediterranean Raptor Migration Network. We acknowledge the support provided by COST-European Cooperation in Science and Technology through the Action ES1305 "European Network for the Radar Surveillance of Animal Movement" (ENRAM).

\section{Competing interests}

The authors declare that they have no competing interests.

Received: 14 March 2017 Accepted: 29 August 2017

Published online: 04 September 2017

\section{References}

Agostini N, Coleiro C, Panuccio M. Autumn migration of Marsh Harriers across the central Mediterranean in 2002. Ring. 2003;25:47-52.

Agostini N, Logozzo D. Osservazioni sulla migrazione autunnale dei rapaci sull'Appennino calabrese. Rivista Italiana di Ornitologia. 1995;64:117-20.

Agostini N, Logozzo D. Autumn migration of Accipitriformes through Italy en route to Africa. Avocetta. 1997;21:174-9.

Agostini N, Logozzo D. Migration and wintering distribution of the Marsh Harrier (Circus aeruginosus) in southern Italy. Buteo. 2000;11:19-24.

Agostini N, Panuccio M. Western Marsh Harrier (Circus aeruginosus) migration through the Mediterranean Sea: a review. J Raptor Res. 2010;44:136-42.

Agostini N, Panuccio M, Pasquaretta C. Morphology, flight performance, and water crossing tendencies of Afro-Palearctic raptors during migration. Curr Zool. 2015;61:951-8.

Bergmann C. Ueber die Verhältnisse der Wärmeökonomie der Thiere zuihrer Grösse. Gottinger Studien. 1847;3:595-708.

BirdLife International. Birds in Europe: population estimates, trends and conservation status. Cambridge: BirdLife Conservation Series No 12; 2004.

Blackburn TM, Gaston KJ, Loder N. Geographic gradients in body size: a clarification of Bergmanns rule. Divers Distrib. 1999;5:165-74.

Clarke R. The Marsh Harrier. London: Hamlyn; 1995.

Coleiro C, Portelli P, Agostini N. Autumn migration of Marsh Harriers over Malta. Abstracts of the second international conference on raptors, Urbino, Italy. Raptor Research Foundation; 1996.

Cramp S, Simmons KEL, editors. Handbook of the birds of Europe, the Middle East and North Africa: the birds of the Western Palearctic, vol. 2. Oxford: Oxford University Press; 1983.

del Hoyo J, Elliott A, Sargatal J. Handbook of the birds of the world, vol 2: New World vultures to guineafoul. Barcelona: Lynx Edicions; 1994.

Ferguson-Lees J, Christie DA. Raptors of the world. London: Helm; 2001.

Forsman D. The raptors of Europe and the Middle East: a handbook of field identification. London: T \& AD Poyser; 1999.

Forsman D. Flight identification of raptors of Europe, North Africa and the Middle East. London: Christopher Helm; 2016.

Goldreich Y, Karni O. Climate and precipitation in the Arava Valley, Israel. Isr J Earth Sci. 2001:50:53-9.

Kerlinger P. Flight strategies of migrating hawks. Chicago: University of Chicago Press; 1989.

Kjellén N. Differential timing of autumn migration between sex and age groups in raptors at Falsterbo, Sweden. Ornis Scand. 1992;23:420-34.

Mateos-Rodríguez M, Liechti F. How do diurnal long-distance migrants select flight altitude in relation to wind? Behav Ecol. 2012;23:403-9.

Mellone U, Klaassen RHG, Garcia-Ripolles C, Limiñana R, Lopez-Lopez P, Pavon $D$, Strandberg R, Urios V, Vardakis M, Alerstam T. Interspecific comparison of the performance of soaring migrants in relation to morphology, meteorological conditions and migration strategies. PLOS ONE. 2012;7:e39833.

Newton I. Population ecology of raptors. London: T \& A D Poyser; 1979.

Olson V, Davies RG, Orme CDL, Thomas GH, Meiri S, Blackburn TM, Gaston KJ, Owens IPF, Bennett PM. Global biogeography and ecology of body size in birds. Ecol Lett. 2009;12:249-59.

Panuccio M. Wind effects on the visible raptor migration in spring at the Strait of Messina, Southern Italy. J Raptor Res. 2011;45:88-92.

Panuccio M, Chiatante G, Tarini D. Two different migration strategies in response to an ecological barrier: Western Marsh Harriers and juvenile European Honey Buzzards crossing the central-eastern Mediterranean in autumn. J Biol Res-Thessaloniki. 2013a;19:10-8.

Panuccio M, D'Amicis B, Canale E, Roccella A. Sex and age ratios of Marsh Harriers Circus aeruginosus wintering in central-southern Italy. Avocetta. 2005;29:13-7

Panuccio M, Mellone U, Muner L. Differential wintering area selection in Eurasian Marsh Harrier (Circus aeruginosus): a ringing recoveries analysis. Bird Study. 2013b:60:52-9. 
Panuccio M, Stanzione V, Catoni C, Santini M, Dell'Omo G. Radar tracking reveals influence of crosswinds and topography on migratory behavior of European honey buzzards. J Ethol. 2016;34:73-7.

Sammut M, Fenech N, Pirotta JE. Autumn raptor migration over Malta. Br Birds. 2013;106:217-23.

Simmons RE. Harriers of the world. Their behaviour and ecology. Oxford: Oxford University Press; 2000
Shirihai H, Yosef R, Alon D, Kirwan GM, Spaar R. Raptor migration in Israel and the Middle East. Eilat: International Birding \& Research Centre; 2000.

Spaar R, Bruderer B. Migration by flapping or soaring: flight strategies of Marsh, Montagu's and Pallid harriers in southern Israel. Condor. 1997;99:458-69.

Taylor PD, Brzustowski JM, Matkovich C, Peckford M, Wilson D. radR: an opensource platform for acquiring and analysing data on biological targets observed by surveillance radar. BMC Ecol. 2010;10:22.

\section{Submit your next manuscript to BioMed Central and we will help you at every step:}

- We accept pre-submission inquiries

- Our selector tool helps you to find the most relevant journal

- We provide round the clock customer support

- Convenient online submission

- Thorough peer review

- Inclusion in PubMed and all major indexing services

- Maximum visibility for your research

Submit your manuscript at

www.biomedcentral com/submit 